\title{
Kepastian dan Perlindungan Hukum dalam Pendirian Perseroan Terbatas Melalui Sistem Administrasi Badan Hukum Menurut Undang-Undang Nomor 40 Tahun 2007 tentang Perseroan Terbatas
}

\author{
Arman Lany*
}

\begin{abstract}
Abstrak
Pengaturan Sistem Administrasi Badan Hukum (SABH) dalam Undang-Undang Nomor 40 Tahun 2007 tentang Perseroan Terbatas (UU PT) dalam rangka untuk mewujudkan kepastian hukum dan perlindungan hukum bagi stakeholders, belum sepenuhnya tercapai. Hal ini disebabkan praktik SABH tidak sejalan dengan pengaturan dalam UU PT dan peraturan pelaksanaan dari SABH telah beberapa kali mengalami perubahan. Fungsi pengesahan akta pendirian Perusahaan Terbatas (PT) melalui SABH dalam praktik dihubungkan dengan kepastian hukum dan perlindungan hukum bagi para pihak pemangku kepentingan, hanya untuk memperoleh status badan hukum PT dan belum dilaksanakan sesuai prosedur hukum administrasi negara. Hal ini disebabkan Menteri Hukum dan Hak Asasi Manusia sebagai pihak yang berwenang menerbitkan keputusan badan hukum PT tidak melakukan pemeriksaan dokumen dan kelengkapan administrasi pemerintahan dari pemohon. Praktik SABH ke depan dalam pelaksanaan UU PT untuk dapat lebih mewujudkan kepastian hukum dan perlindungan hukum bagi para pihak pemangku kepentingan, harus ada kesesuaian antara pengaturan dan pelaksanaan sehari-hari.
\end{abstract}

Kata Kunci: kepastian hukum, perlindungan hukum, perseroan terbatas, Sistem Administrasi Badan Hukum, UU PT.

\section{Legal Protection and Certainty of Law On the Establishment of Limited Liability Company (PT) through the System of Administrative Of Legal Entity (SABH) Pursuant to Law Number 40 Year 2007 on Limited Company}

\begin{abstract}
The regulation for the System Administration of Legal Entity (SABH) in Law Number 40 Year 2007 on Limited Liability Company to provide legal certainty and protection for stakeholders has not yet been fully realized. This is because the practice of SABH is not accordance with the law on Limited Liability Company. Also, the regulation of the SABH has undergone multiple revisions. The ratification function for establishment of a Limited Liability Company through $S A B H$ in order to gain legal certainty and protection is often only done to gain the status of Limited Liability Company, while not heeding the administrative procedure. The Ministry of
\end{abstract}

PADJADJARAN Jurnal IImu Hukum Volume 2 Nomor 2 Tahun 2015 [ISSN 2460-1543] [e-ISSN 2442-9325]

* Profesional, Jl. Demak Nomor 39 04/06 Perumahan Jakapermai, Bekasi Barat, armanlany@hotmail.com, S.H. (Universitas Sriwijaya), M.H. (Universitas Padjadjaran). 
Law and Human Rights, as a body with the authority to grant the status of Limited Liability Company often does not conduct a proper document and requirement check to fulfill the administrative demand. It is expected in the future that the practice of SABH in the implementation of the Law on Limited Liability Company can also grant legal certainty and protection for the stakeholders; the regulation and the real implementation have to be consistent.

Keywords: law certainty, protection of law, limited company, System Administration of Legal Entity, limited company law.

\section{A. Pendahuluan}

Negara hukum yang dianut oleh Indonesia, dilihat dari segi hukum dalam arti materiil bukan dalam arti formal. Pengertian secara materiil diistilahkan dengan negara kesejahteraan (welfare state) atau negara kemakmuran. ${ }^{1}$ Pada awalnya, upaya untuk mencapai kesejahteraan sepenuhnya diserahkan kepada rakyat tanpa campur tangan pemerintah. Negara hanya menjaga ketertiban masyarakat dan tidak terlalu aktif dalam menjaga keperluan rakyat. Hal ini mirip dengan konsep negara polisi atau 'negara penjaga malam'. Selanjutnya, seiring dengan berkembangnya ilmu pengetahuan dan teknologi serta sebagai akibat dari pengaruh tidak baik konsep negara penjaga malam, menimbulkan masalah sosial dalam masyarakat sehingga memaksa negara harus campur tangan secara aktif dalam kehidupan masyarakat. ${ }^{2}$

Negara hukum merupakan negara yang berlandaskan pada hukum yang menjamin keadilan bagi seluruh rakyatnya. Hal ini mengandung arti, bahwa segala tindakan alat-alat perlengkapan negara atau penguasa diatur oleh hukum. Hal ini sebagai wujud rasa keadilan bagi pergaulan hidup warganya. ${ }^{3}$ Keadilan merupakan cerminan cita-cita rakyat sebagaimana tertuang dalam konstitusi suatu negara. Ukuran keadilan merupakan salah satu tolok ukur keberhasilan suatu negara hukum demi terwujudnya negara kesejahteraan. ${ }^{4}$

Salah satu upaya untuk mencapai tujuan pembangunan nasional diperlukan pembangunan ekonomi yang bertujuan untuk tercapainya keadaan masyarakat yang adil dan makmur berdasarkan Pancasila dan Undang-Undang Dasar 1945 (UUD 1945), sebagaimana diamanatkan dalam alinea ke-4 Pembukaan UUD 1945 dan Pasal 33 UUD 1945. Negara memiliki tanggung jawab untuk mewujudkan

1 E.Utrecht, Pengantar Hukum Administrasi Negara Indonesia cetakan ke-4, Bandung: Universitas Negeri Padjadjaran, 1960, hlm. 21-22.

2 Man S. Sastrawidjaja, Bunga Rampai Hukum Dagang, Bandung: Alumni, 2005, hlm. 3.

3 Wiratni Ahmadi, Perlindungan Hukum Bagi Wajib Pajak Dalam Penyelesaian Sengketa Pajak, Bandung, Refika Aditama, Cet ke 1, 2006, hlm. 2.

4 Ibid. 
kesejahteraan, kemakmuran, dan keadilan sosial bagi seluruh rakyat Indonesia.

Tujuan yang hendak dicapai oleh negara hukum Indonesia berdasarkan Pembukaan alinea ke-4 UUD 1945 adalah mencapai masyarakat adil dan makmur, baik spiritual maupun material secara merata yang berdasarkan Pancasila. Indonesia sebagai negara hukum yang memiliki karakteristik mandiri, demikian sebagaimana dikemukakan oleh Rukmana Amanwinata. ${ }^{5}$ Hal ini mengandung makna bahwa negara hukum Indonesia memiliki ciri khas yang tidak sama dengan negara lainnya, yakni karakteristik yang berpegang teguh pada falsafah Pancasila. ${ }^{6}$ Hukum sebagai dasar dalam segala aktivitas kehidupan bermasyarakat, bernegara, dan berbangsa untuk mencapai masyarakat adil dan makmur secara merata. Hal ini yang menyebabkan segala tindakan, baik yang dilakukan oleh penyelenggara negara maupun rakyat, harus sesuai atau tidak bertentangan dengan hukum yang berlaku. $^{7}$

Fungsi dan peranan hukum dalam pembangunan nasional sebagaimana dikemukakan oleh Mochtar Kusumaatmadja dalam Teori Hukum Pembangunan, diantaranya adalah mempertahankan ketertiban melalui kepastian hukum dan hukum sebagai kaidah sosial harus dapat mengatur proses perubahan dalam masyarakat. Baik perubahan maupun ketertiban merupakan tujuan awal dari masyarakat yang sedang berkembang, oleh karena itu hukum menjadi suatu sarana yang tidak dapat diabaikan dalam proses pembangunan. Penerapan fungsi hukum tersebut hanya dapat terwujud jika hukum dijalankan oleh suatu kekuasaan dalam batas rambu-rambu yang ditentukan dalam hukum itu. ${ }^{8}$

Salah satu tugas hukum adalah menjamin adanya kepastian hukum dalam hubungan-hubungan hukum yang terdapat dalam pergaulan masyarakat. ${ }^{9}$ Prinsip penting dalam negara hukum adalah perlindungan yang sama (equal protection) atau persamaan dalam hukum (equality before the law). ${ }^{10}$ Hukum berfungsi sebagai perlindungan kepentingan manusia agar kepentingan manusia terlindungi, maka hukum harus dilaksanakan secara normal, damai, dan dapat pula terjadi karena pelanggaran hukum. ${ }^{11}$ Pelanggaran hukum terjadi ketika subjek hukum tertentu

5 Rukmana Amanwinata, "Pengaturan dan batas Implementasi Kemerdekaan Berserikat dan Berkumpul dalam Pasal 28 UUD 1945", Disertasi Fakultas Hukum Pasca Sarjana Universitas Padjadjaran, Bandung, 1996, hlm. 109.

6 Wiratni Ahmadi, Op. cit., hlm. 3.

7 Ibid.

8 Mochtar Kusumaatmadja, Fungsi dan Perkembangan Hukum dalam Pembangunan Nasional, Bandung, Bina Cipta (tanpa tahun), dalam Romli Atmasasmita, Teori Hukum Integratif Rekonstruksi Terhadap Teori Hukum Pembangunan dan Teori Hukum Progresif, Yogyakarta: Genta Publishing, Cet. Pertama, 2012, hlm. 65-66.

9 E.Utrecht/Moh. Saleh Djindang, Pengantar Dalam Hukum Indonesia, Jakarta: Ichtiar Baru dan Sinar Harapan, 1989, hlm. 13.

10 Munir Fuady, Teori Negara Hukum Modern (Rechtstaat), Bandung: Refika Aditama, 2009, hlm. 207.

11 Sudikno Mertokusumo, Mengenal Hukum Suatu Pengantar, Yogyakarta: Liberty, 1996, hlm. 140. 
tidak menjalankan kewajibannya sebagaimana semestinya atau melanggar hak-hak subjek hukum lainnya. Pelanggaran atas hak-hak subjek hukum harus memperoleh perlindungan hukum. ${ }^{12}$

Berkaitan dengan pendirian Perusahaan Terbatas (PT) sebagai badan hukum berhubungan erat dengan penegakan hukum sehingga merupakan persoalan yang tidak kalah penting dalam rangka meningkatkan iklim investasi terutama bagi investor asing yang menanamkan modalnya di Indonesia. Proses pengesahan pendirian PT sebagai badan hukum melalui Sistem Administrasi Badan Hukum $(\mathrm{SABH})$, masih kurang ditopang oleh perangkat hukum yang memadai sehingga diantara pasal-pasal dalam Undang-Undang Nomor 40 Tahun 2007 tentang Perseroan Terbatas (UU PT 2007) yang berkaitan dengan hal ini belum dijalankan sebagaimana semestinya, yang berakitbat pada ketidakharmonisan dalam pelaksanaannya. Ketidakharmonisan peraturan ini dapat dilihat salah satunya melalui kewajiban penyampaian secara fisik surat permohonan yang dilampiri dokumen pendukung dalam jangka waktu paling lambat 30 hari terhitung sejak tanggal pernyataan tidak berkeberatan sebagaimana pengaturan Pasal 10 ayat (5) UUPT 2007, yang belum dijalankan dalam pelaksanaan SABH menurut UU PT 2007.

Berdasarkan uraian di atas, dapat dirumuskan permasalahan-permasalahan hukum sebagai berikut:

1. Bagaimana pengaturan SABH dalam UU PT 2007 dalam kajian kepastian hukum dan Perlindungan hukum bagi stakeholders?

2. Bagaimana fungsi pengesahan akta pendirian PT melalui SABH dalam praktik, dihubungkan dengan kepastian hukum dan perlindungan hukum bagi stakeholders?

3. Bagaimana konsep SABH ke depan dalam pelaksanaan UU PT 2007 dapat lebih mewujudkan kepastian hukum dan perlindungan hukum bagi stakeholders?

Tulisan ini merupakan hasil penelitian dengan menggunakan metode pendekatan yuridis normatif. Penelitian dilakukan dalam 2 tahap, yakni: penelitian kepustakaan (library research) dan penelitian lapangan (field research). Penelitian kepustakaan bertujuan untuk mengkaji, meneliti, dan menelusuri data sekunder, baik berupa bahan hukum primer, bahan hukum sekunder maupun bahan hukum tersier. Penelitian lapangan bertujuan mencari data lapangan yang berfungsi sebagai pendukung data sekunder. Hasil penelitian ini diharapkan dapat memberikan manfaat bagi pengembangan ilmu hukum pada umumnya dan hukum perseroan khususnya.

\footnotetext{
12 Ridwan H. R., Hukum Administrasi Negara, Jakarta, Raja Grafindo Persada, 2006, hlm. 280.
} 


\section{B. Pendirian Perseroan Terbatas Melalui Sistem Administrasi Badan Hukum (SABH)}

Proses awal pendirian PT diatur dalam Pasal 7 UU PT 2007, pasal tersebut menentukan bahwa PT didirikan oleh 2 orang atau lebih dengan akta notaris yang dibuat dalam bahasa Indonesia. Selanjutnya, dalam penjelasan Pasal 7 ayat (1) UU PT 2007 disebutkan bahwa yang dimaksud dengan orang adalah orang perorangan, baik warga negara Indonesia maupun asing atau badan hukum Indonesia atau asing. Lebih lanjut, penjelasan pasal tersebut menegaskan prinsip yang berlaku berdasarkan undang-undang ini bahwa pada dasarnya sebagai badan hukum, PT dibentuk berdasarkan perjanjian dan karenanya mempunyai lebih dari 1 orang pemegang saham.

Mengenai tata cara dan prosedur permohonan untuk memperoleh keputusan pengesahan akta pendirian PT dari Menteri diatur dengan menggunakan Sistem Administrasi Badan Hukum yang semula disingkat Sisminbakum dan sekarang disingkat SABH. ${ }^{13}$ SABH merupakan sebuah sistem komputerisasi pendirian badan hukum PT yang diselenggarakan oleh Direktorat Jenderal Administrasi Hukum Umum (Dirjen AHU) pada Kementerian Hukum dan Hak Asasi Manusia (Kemenkumham), guna mempercepat proses pembuatan serta memperbaiki sistem pendokumentasian. Pemberlakuan SABH didasarkan pada pertimbangan untuk mengantisipasi perkembangan bisnis yang sangat cepat dan kompetitif di era globalisasi. Pada era globalisasi diperlukan peningkatan fungsi pelayanan jasa hukum dilingkungan Dirjen AHU guna mendukung kemajuan dunia usaha di tanah air. Melalui sistem online SABH diharapkan pengadministrasian PT dapat lebih cepat, mudah, murah, dan terbuka. ${ }^{14}$

Suatu PT akan sah sebagai badan hukum setelah memperoleh pengesahan dari Menteri, pengesahan diterbitkan dalam bentuk keputusan Menteri yang disebut keputusan pengesahan badan hukum perseroan, seperti dinyatakan Pasal 7 ayat (4) UU PT 2007. Tata cara dan prosedur permohonan untuk memperoleh keputusan pengesahan badan hukum PT dari Menteri, diatur pada Pasal 9 dan 10 UU PT 2007, dan Peraturan Menteri Hukum dan Hak Asasi Manusia Nomor 4 Tahun 2014 tentang Tata Cara Pengajuan Permohonan Pengesahan Badan Hukum dan Persetujuan Perubahan Anggaran Dasar Serta Penyampaian Pemberitahuan Perubahan Anggaran Dasar dan Perubahan Data Perseroan Terbatas (Permenkumham 4/2014).

13 Dapat dilihat Pasal 1 (3) Peraturan Menteri Hukum dan HAM Nomor 4 Tahun 2014 tentang Tata Cara Pengajuan Permohonan Pengesahan Badan Hukum dan Persetujuan Perubahan Anggaran Dasar Serta Penyampaian Pemberitahuan Perubahan Anggaran Dasar dan Perubahan Data Perseroan.

${ }^{14}$ Iswi Hariyani, R. Serfianto Dibyo Purnomo, Cita Yustisia Serfiyani, Panduan Praktis SABH, Jakarta, Pustaka Yustisia, 2011, hlm. 164. 
Menurut ketentuan Pasal 9 ayat (1) UU PT 2007, untuk memperoleh Keputusan Menteri mengenai pengesahan badan hukum PT sebagaimana dimaksud Pasal 7 ayat (4) UU PT 2007, pendiri secara bersama-sama mengajukan permohonan. Selanjutnya, menurut Pasal 9 ayat (3) UU PT 2007 dalam hal pendiri tidak mengajukan sendiri permohonan pengesahan, pendiri hanya dapat memberikan kuasa kepada notaris. Dengan demikian, berdasarkan ketentuan Pasal 9 ayat (1) dan ayat (3) UU PT 2007 yang dapat mengajukan permohonan pengesahan badan hukum PT kepada Menteri adalah pendiri PT secara bersama-sama atau pemberian kuasa kepada notaris.

Prosedur pengajuan permohonan pengesahan badan hukum PT diajukan oleh pemohon melalui jasa teknologi informasi badan hukum secara elektronik. Jasa teknologi informasi sistem administrasi badan hukum adalah jenis pelayanan yang diberikan kepada masyarakat dalam proses pengesahan badan hukum perseroan, demikian pengaturan Pasal 9 ayat (1) UU PT 2007 berikut penjelasannya. Selanjutnya, menurut Pasal 1 ayat (3) Permenkumham tersebut yang dimaksud dengan $\mathrm{SABH}$ adalah sistem pelayanan administrasi perseroan secara elektronik yang diselenggarakan oleh Dirjen AHU. Permenkumham 4/2014 tersebut mengatur baik mengenai pengajuan permohonan pengesahan badan hukum PT maupun permohonan persetujuan atau pemberitahuan perubahan anggaran dasar dan pemberitahuan perubahan data PT.

Pengajuan permohonan pengesahan badan hukum PT melalui SABH kepada Menteri menurut ketentuan Pasal 9 ayat (1) UU PT 2007, dilakukan dengan cara mengisi format isian yang memuat sekurang-kurangnya:

1. Nama dan tempat kedudukan perseroan;

2. Jangka waktu berdirinya perseroan;

3. Maksud dan tujuan serta kegiatan usaha perseroan;

4. Jumlah modal dasar, modal ditempatkan, dan modal disetor;

5. Alamat lengkap perseroan.

Pada Pasal 1 ayat (5) Permenkumham 4/2014 tersebut ditentukan, bahwa format isian adalah bentuk pengisian data yang dilakukan secara elektronik untuk permohonan pengajuan pemakaian nama perseroan, pengesahan badan hukum dan pemberian persetujuan perubahan anggaran dasar, penyampaian pemberitahuan perubahan anggaran dasar dan perubahan data perseroan. Menurut ketentuan Pasal 3 ayat (1) Permenkumham tersebut, permohonan pengesahan badan hukum PT yang diajukan oleh notaris melalui SABH dengan cara mengisi format isian, setelah pemakaian nama PT disetujui oleh Menteri. Ditegaskan pula dalam Pasal 9 ayat (2) UU PT 2007, bahwa pengisian format isian baru dapat dilakukan oleh notaris setelah didahului dengan pengajuan nama PT. Setelah nama PT disetujui oleh Menteri, notaris yang bersangkutan diperkenankan 
melakukan pengisian format isian.

Jangka waktu permohonan untuk memperoleh keputusan Menteri melalui SABH menurut Pasal 10 ayat (1) UU PT 2007 harus diajukan kepada Menteri paling lambat 60 hari terhitung sejak tanggal akta pendirian ditandatangani, dilengkapi keterangan mengenai dokumen pendukung. Selanjutnya, Pasal 10 ayat (9) UU PT 2007 ditentukan bahwa apabila lewat dari jangka waktu tersebut maka akta pendirian menjadi batal karena hukum dan PT yang belum memperoleh status badan hukum menjadi bubar karena hukum dan pemberesannya dilakukan oleh pendiri.

Berdasarkan konsep negara hukum dalam kaitannya dengan pendirian PT, harus memperhatikan ketentuan hukum yang berlaku sehingga apa yang menjadi tujuan dari hukum itu sendiri diharapkan akan tercapai. Hal ini berarti bahwa dalam pelaksanaannya, dimulai dari para pihak mendirikan PT dihadapan notaris, dilanjutkan dengan proses permohonan pengesahan pendirian PT sebagai badan hukum oleh Menteri, dan pengumuman PT dalam Tambahan Berita Negara Republik Indonesia (TBNRI). Ke semua proses tersebut harus sesuai dengan ketentuan hukum yang berlaku.

Ketentuan Pasal 10 ayat (9) UU PT 2007 tersebut tidak konsisten karena akta pendirian PT merupakan hasil dari suatu perbuatan hukum berupa perjanjian antara pihak-pihak yang mendirikan PT. Suatu perjanjian dikatakan batal demi hukum jika bertentangan dengan undang-undang, ketertiban umum atau kesusilaan. Dalam hubungan dengan syarat-syarat sahnya perjanjian menurut Pasal 1320 KUH Perdata, maka perjanjian pendirian PT tersebut tidak mempunyai objek tertentu atau kausa yang halal.

Mengenai format pendirian dan keterangan tentang dokumen pendukung yang telah sesuai dengan ketentuan peraturan perundang-undangan, Menteri langsung menyatakan 'tidak berkeberatan' atas permohonan pengesahan yang diajukan dan pernyataan tidak keberatan tersebut dilakukan Menteri langsung melalui SABH secara elektronik, demikian pengaturan Pasal 10 ayat (3) UU PT 2007.Menurut penjelasan pasal tersebut yang dimaksud dengan 'langsung' dalam ketentuan ini adalah pada saat yang bersamaan dengan saat pengajuan permohonan diterima.

Selanjutnya menurut Pasal 10 ayat (4) UU PT 2007, apabila format isian pendirian dan keterangan mengenai dokumen pendukung tidak sesuai dengan ketentuan peraturan perundang-undangan, Menteri langsung memberitahukan penolakan beserta alasannya kepada pemohon secara elektronik. Dalam jangka waktu paling lambat 30 hari terhitung sejak tanggal pernyataan tidak berkeberatan atas permohonan pengesahan badan hukum yang diajukan notaris, maka berbarengan dengan pernyataan tidak keberatan itu notaris wajib menyampaikan secara fisik surat permohonan pengesahan beserta lampiran dokumen pendukung, 
dan dibuktikan dengan tanda terima, seperti ditegaskan Pasal 10 ayat (5) UUPT 2007. Dokumen pendukung sebagaimana dimaksud berupa surat pernyataan secara elektronik dari pemohon tentang dokumen untuk pendirian PT yang telah lengkap,seperti dimaksud Pasal 13 ayat (2) Permenkumham 4/2014.

Praktik SABH PT berkaitan dengan Pasal 10 ayat (4) di atas, dalam pelaksanaannya belum dijalankan sebagaimana semestinya. Pemohon hanya diwajibkan membuat pernyataan secara elektronik yang berisikan tentang kelengkapan dan kebenaran mengenai dokumen pendukung.Untuk mengetahui kebenaran format isian dan keterangan mengenai dokumen pendukung, Menteri harus memeriksa baik format isian maupun dokumen pendukung tersebut, dengan demikian Menteri dapat menerima atau menolak permohonan yang diajukan oleh pemohon. Pengaturan SABH dalam pelaksanaannya belum diterapkan sebagaimana semestinya. Hal ini akan membawa konsekwensi, bahwa kepastian hukum dan perlindungan hukum sebagai tujuan dari hukum itu sendiri tidak akan tercapai.

Apabila semua persyaratan sebagaimana diuraikan di atas telah dipenuhi secara lengkap, Menteri menerbitkan keputusan tentang pengesahan badan hukum PT yang ditandatangani secara elektronik paling lambat 14 hari . Ketentuan tersebut diatur dalam Pasal 10 ayat (6) UUPT 2007. Penjelasan pasal tersebut menegaskan, bahwa yang dimaksud dengan "tanda tangan secara elektronik" adalah tanda tangan yang dilekatkan atau disertakan pada data elektronik oleh pejabat yang berwenang yang membuktikan keotentikan data yang berupa gambar elektronik dari tanda tangan pejabat yang berwenang tersebut yang dibuat melalui media komputer.

Apabila persyaratan tentang jangka waktu dan kelengkapan dokumen pendukung sebagaimana dimaksud tidak dipenuhi, Menteri langsung memberitahukan hal tersebut kepada pemohon secara elektronik, dan pernyataan tidak berkeberatan yang telah diberikan menjadi gugur. Pemohon dapat mengajukan kembali permohonan untuk memperoleh keputusan Menteri mengenai pengesahan badan hukum PT yang telah gugur. Ketentuan tersebut diatur dalam Pasal 10 ayat (7) dan ayat (8) UU PT 2007.

Praktik SABH dalam kaitannya dengan ketentuan Pasal 10 ayat (5) UU PT 2007 juga belum dijalankan sebagaimana semestinya. Dalam pelaksanaannya pemohon tidak menyampaikan secara fisik surat permohonan berserta lampiran dokumen pendukung. Notaris hanya membuat surat pernyataan mengenai kebenaran dokumen pendukung secara elektronik. Notaris bertanggung jawab secara hukum mengenai kebenaran dokumen pendukung sebagaimana dimaksud. Praktik SABH sebagaimana tersebut tidak sejalan dengan ketentuan perundang-undangan yang berlaku sehingga kepastian hukum dan perlindungan hukum belum terwujud. 
Ketentuan Pasal 10 ayat (5) UU PT 2007 sudah tidak sesuai dengan perkembangan ilmu pengetahuan dan teknologi yang begitu pesat. Seharusnya melalui SABH tidak diperlukan lagi penyampaian permohonan secara fisik karena hal ini semata-mata hanya bersifat teknis administratif.

\section{Pengesahan Akta Pendirian Perseroan Terbatas Sebagai Tindakan Konstitutif}

Pemerintah dalam melaksanakan tugas-tugasnya dapat melakukan 2 macam tindakan, yaitu: ${ }^{15}$

1. Tindakan-tindakan yang tidak langsung menimbulkan akibat-akibat hukum;

2. Tindakan-tindakan yang secara langsung menimbulkan akibat-akibat hukum.

Tindakan yang kedua ini dalam bahasa Belanda disebut dengan istilah 'beschikking'.

Definisi beschikking atau penetapan menurut A.M. Donner adalah: ${ }^{16}$

"de ambtelijke bestuurshandeling, waardoor eenzijdig en opzettelijk in een bepaald geval een bestaande rechtsverhouding of rechtstoestand wordt vastesteld of een nieuwe rechtsverhouding of rechtstoestand in leven wordt geroepen dan wel het een of ander wordt geweigerd"

Terjemahan Amrah Muslimin: "Penetapan adalah tindakan pemerintah dalam jabatan, yang secara sepihak dan disengaja dalam suatu ikhwal tertentu, menetapkan suatu hubungan hukum atau keadaan hukum yang sedang berjalan atau menimbulkan suatu hubungan hukum atau keadaan hukum baru, atau menolak salah satu yang dimaksud".

Berdasarkan definisi A.M. Donner tersebut terdapat unsur-unsur penetapan sebagai berikut: ${ }^{17}$

1. Tindakan pemerintah dalam jabatan;

2. Secara sepihak dengan sengaja;

3. Dalam suatu ikhwal tertentu;

4. Menetapkan suatu hubungan hukum atau keadaan hukum yang sedang berjalan; atau menimbulkan suatu hubungan hukum atau keadaan hukum baru; atau menolak salah satu akibat yang sedang berjalan atau keadaan hukum baru.

Jabatan menurut Prins merupakan subjek dalam hukum administrasi, dan secara umum di luar hukum administrasi disebut fungsi. Jabatan adalah suatu lingkungan pekerjaan (tugas) tetap dalam hubungan dengan keseluruhan tugas negara, jadi dalam jabatan itu tercakup kewenangan-kewenangan khusus, sehingga unsur 'tindakan pemerintah dalam jabatan' tidak dapat ditafsirkan lain dari pada tindakan dalam bidang pemerintahan berdasarkan kewenangan khusus. ${ }^{18}$ Unsur

15 A.M. Donner, dalam Amrah Muslimin, Beberapa Asas-Asas dan Pengertian-Pengertian Pokok Tentang Administrasi dan Hukum Administrasi, Bandung: Alumni, 1980, hlm. 107.

16 Ibid., hlm. 109-110.

17 Ibid. 
secara sepihak dalam suatu penetapan berdasarkan kewenangan khusus dalam jabatan yang diembannya dan bukan berdasarkan kemauan pribadinya, sehingga suatu keputusan atau penetapan yang dibuat adalah berdasarkan peraturan hukum dan kewenangan jabatannya. ${ }^{19}$

Mengenai unsur hal tertentu, penetapan berhubungan dengan suatu ikhwal yang kongkrit dan hal tertentu berkaitan tidak saja dengan orang atau benda, akan tetapi juga mengenai asal orang/benda/perbuatan/badan yang bersangkutan yang tekait dalam suatu ikhwal tertentu yang kongkrit, dalam hal ini kita berhadapan dengan suatu 'penetapan'. Sebagai contoh: perintah polisi pada suatu rapat yang dihadiri lebih dari seratus orang pada waktu tertentu agar bubar, dan oleh karena rapat tertentu maka perintah ini termasuk penetapan. ${ }^{20}$

Unsur keempat sebagai unsur menimbulkan akibat hukum secara langsung, yaitu bersifat: ${ }^{21}$

1. Menetapkan dalam arti menguatkan suatu hubungan hukum/keadaan hukum yang sedang berjalan, misalnya keterangan tentang hubungan seorang anak dengan bapak atau ibunya karena pengakuan atau adopsi;

2. Menimbulkan suatu hubungan hukum/keadaan hukum baru, contohnya pemberian konsesi pada suatu PT untuk mencari minyak bumi;

3. Penolakan salah satu akibat hukum, yang dimaksud pada nomor 1 dan 2 di atas, umpamanya penolakan izin konsesi bangunan atau usaha.

Uraian di atas menggambarkan suatu pengertian dari penetapan (beschikking). Amrah Muslimin menggunakan istilah 'penetapan' untuk terjemahan beschikking dan menurut pendapatnya penetapan adalah tindakan hukum (rechtshandeling) pemerintah secara sepihak yang menimbulkan akibat hukum dalam suatu ikhwal yang kongkrit berdasarkan kewenangan khusus jabatan. Utrecht memakai kata 'ketetapan' sebagai terjemahan dari kata beschikking, ${ }^{22}$ sedang Kuntjoro Purbopranoto menggunakan istilah 'keputusan' untuk terjemahan beschikking. Lebih lanjut, Amrah Muslimin mengemukakan bahwa keputusan merupakan suatu 'pengertian genus', yaitu tiap-tiap tindakan pemerintah dalam arti luas disebut keputusan atau surat keputusan, baik bersifat peraturan maupun bersifat mengatur sesuatu yang konkrit, misalnya pengangkatan pegawai, selalu digunakan istilah 'memutuskan' dan 'menetapkan', selanjutnya isi keputusan yang sebenarnya. Suatu keputusan mengandung suatu ketetapan, yang menurut sifatnya merupakan suatu peraturan atau penetapan. Istilah penetapan dapat merupakan suatu instruksi, perintah, pengesahan atau penolakan, perizinan dan lain-lain. ${ }^{23}$

\footnotetext{
18 Ibid.

19 Ibid., hlm. 111.

20 Ibid., hlm. 112-113.

21 Ibid.

22 E. Utrecht, Op. cit., hlm. 68.
} 
Suatu penetapan (beschikking) sebagai suatu keputusan yang dikeluarkan oleh organ pemerintah dalam kewenangan khusus yang diberikan berdasarkanjabatan dan peraturan hukum, karenanya harus memenuhi syarat-syarat baik formil maupun materil agar dapat berlaku sah. Persyaratan formil dimaksud meliputi: prosedur/cara pembuatan penetapan, bentuk penetapan, pemberitahuan penetapan pada yang bersangkutan. Persyaratan materil mencakup hal-hal tentang kewenangan menurut lingkup wilayah hukum (ressort) dari jabatan (ruimtegebied); kewenangan menurut ruang lingkup persoalan (zakengebied); harus dibuat tanpa adanya kekurangan-kekurangan yuridis dalam pembentukannya; dan keempat penetapan harus menuju sasaran yang tepat. ${ }^{24}$

Keputusan administrasi pemerintahan yang juga disebut Keputusan Tata Usaha Negara atau Keputusan Administrasi Negara merupakan ketetapan tertulis yang dikeluarkan oleh badan dan/atau pejabat pemerintah dalam penyelenggara negara, seperti pengaturan Pasal 1 angka 7 Undang-Undang Nomor 30 Tahun 2014 tentang Administrasi Pemerintahan (selanjutnya disingkat UU 30/2014). Keputusan yang ditetapkan oleh Pejabat pemerintahan untuk mengatasi persoalan konkret yang dihadapi dalam penyelenggara pemerintahan dalam hal peraturan perundang-undangan yang memberikan pilihan, tidak mengatur, tidak lengkap atau tidak jelas, dan/atau adanya stagnasi pemerintahan (Pasal 1 angka 9 UU 30/2014).

Undang-undang administrasi pemerintahan bertujuan untuk menciptakan tertib administrasi pemerintahan, menciptakan kepastian hukum, mencegah terjadinya penyalahgunaan wewenang. Selanjutnya, menjamin akuntabilitas badan dan/atau pejabat pemerintahan, memberikan perlindungan hukum kepada warga masyarakat dan aparatur pemerintahan, melaksanakan ketentuan peraturan perundang-undangan, dan menerapkan asas-asas umum pemerintahan yang baik, serta memberikan pelayanan yang sebaik-baiknya kepada warga masyarakat (Pasal 3 UU 30/2014).

Mengenai kewajiban pejabat pemerintahan dalam melaksanakan kewenangan yang dimiliki harus mematuhi persyaratan dan prosedur pembuatan keputusan dan/atau tindakan serta mematuhi UU 30/2014 dalam menggunakan diskresi. Pejabat dan/atau badan pemerintahan dapat membuat keputusan berbentuk elektronik dan keputusan dalam bentuk elektronik wajib dibuat atau disampaikan apabila keputusan tidak dibuat atau tidak disampaikan secara tertulis. Keputusan berbentuk elektronik berkekuatan hukum sama dengan keputusan yang tertulis dan berlaku sejak diterimanya keputusan tersebut oleh pihak yang bersangkutan. Apabila keputusan dalam bentuk tertulis tidak disampaikan, maka yang berlaku adalah keputusan dalam bentuk elektronik. Jika ada perbedaan antara keputusan

\footnotetext{
${ }^{23}$ Dikutip dari Amrah Muslimin, Op. cit., hlm. 114-116.

24 Ibid., hlm. 123-128.
} 
dalam bentuk elektronik dan tertulis, yang berlaku adalah keputusan dalam bentuk tertulis. Berkaitan dengan keputusan yang mengakibatkan pembebanan keuangan negara wajib dibuat dalam bentuk tertulis. (Pasal 38 ayat (1), ayat (2), ayat (3), ayat (4), ayat (5), dan ayat (6) UU 30/2014).

Selanjutnya, prosedur yang harus dipenuhi berkaitan dengan keputusan yang dikeluarkan oleh pejabat pemerintahan, yakni badan dan/atau pejabat pemerintahan memberikan sosialisasi kepada pihak-pihak yang terlibat mengenai dasar hukum, persyaratan, dokumen, dan fakta yang terkait sebelum menetapkan dan/atau melakukan keputusan. Selanjutnya, pejabat pemerintahan sesuai dengan kewenangannya wajib menyusun dan melaksanakan pedoman umum standar operasional prosedur pembuatan keputusan yang tertuang dalam pedoman umum standar operasional prosedur pembuatan keputusan pada tiap unit kerja pemerintahan. Lebih lanjut, badan dan/atau pejabat pemerintahan sebelum menetapkan keputusan harus memeriksa dokumen dan kelengkapan administrasi pemerintahan dari pemohon.

Status badan hukum PT, diperoleh pada tanggal diterbitkannya keputusan menteri, seperti ketentuan Pasal 7 ayat (4) UU PT 2007. Ketentuan pasal ini mempergunakan sebutan diterbitkannya keputusan menteri untuk memperoleh status badan hukum PT. Hal ini hanya menitikberatkan kepada istilah teknis administratif. ${ }^{25}$ Selanjutnya, fungsi pengesahan oleh menteri sebagaimana dimaksud adalah untuk memperoleh status badan hukum dari PT. ${ }^{26}$ Praktik SABH untuk memperoleh keputusan Menteri mengenai status badan hukum PT dilakukan dengan mengisi format isian yang dimulai dari persetujuan pemakaian nama PT hingga diterbitkannya surat keputusan tentang badan hukum PT seluruhnya dilakukan oleh notaris. Menteri tidak memeriksa dokumen dan kelengkapan administrasi dari pemohon, dan pemohon wajib mengisi surat pernyataan secara elektronik yang menyatakan format pendirian PT dan keterangan mengenai dokumen pendukung telah sesuai dengan ketentuan peraturan perundangundangan serta pemohon bertanggung jawab penuh terhadap format pendirian PT dan keterangan tersebut (Pasal 14 Permenkumham 4/2014). Menkumham selaku pihak yang berwenang menerbitkan keputusan tentang badan hukum PT seharusnya memeriksa dokumen dan dan kelengkapan administrasi dari pemohon. Hal ini merupakan persyaratan dan prosedur pembuatan keputusan dan/atau tindakan serta mematuhi UU 30/2014.

Menurut Suwoto, dalam sistem pembagian kekuasaan berlaku prinsip bahwa setiap kekuasaan wajib dipertanggungjawabkan. ${ }^{27}$ Bagi pemangku kekuasaan pada

\footnotetext{
${ }^{25}$ Man S, Sastrawidjaja dan Rai Mantili, Perseroan Terbatas Menurut Tiga Undang-Undang, Bandung: Alumni, 2008, hlm. 41.

26 Ibid.

27 Suwoto, Kekuasaan dan Tanggung Jawab Presiden Republik Indonesia, Disertasi, Surabaya, Universitas
} 
saat menerima tanggung jawab kekuasaan wajib melaksanakan tanggung jawab yang diemban tersebut secara inklusif. Beban tanggung jawab yang diterima harus sudah dipikirkan bagi setiap penerima kekuasaan. ${ }^{28}$ Lebih lanjut, Suwoto mengatakan bahwa tanggung jawab mengandung dua aspek, yakni aspek internal dan aspek eksternal. Aspek internal pertanggungjawaban diwujudkan dalam bentuk laporan pelaksanaan kekuasaan. Pertanggungjawaban dari aspek eksternal merupakan pertanggungjawaban terhadap pihak ketiga jika dalam melaksanakan kekuasaan itu menimbulkan kerugian. A.D. Belinfante berpandangan bahwa "Niemandkan een bevoegdheid uitoefenen zonder verantwording schuldig te zijn of zonder dat of die uitoefening controle bestaan" (tidak seorangpun dapat melaksanakan kewenangan tanpa memikul kewajiban tanggung jawab atau tanpa ada pelaksanaan pengawasan).

\section{Kepastian Hukum dan Perlindungan Hukum sebagai Tujuan Hukum}

Hukum sebagai sarana yang didalamnya terkandung antara lain nilai atau konsep keadilan, kebenaran, kemanfaatan sosial. Penegakan hukum pada hakikatnya merupakan penegakan ide atau konsep yang abstrak. Penegakan hukum merupakan usaha untuk mewujudkan ide-ide tersebut menjadi kenyataan. ${ }^{31}$ Penegakan hukum oleh instansi penegak hukum yang berwenang, harus menjamin kepastian hukum demi terwujudnya suatu ketertiban dan keadilan dalam kehidupan masyarakat. Ketidakpastian hukum akan menimbulkan kekacauan dalam kehidupan masyarakat, sehingga akan saling berbuat serta bertindak dengan cara main hakim sendiri. Kondisi tersebut menjadikan kehidupan berada dalam suasana social disorganization atau kekacauan sosial. ${ }^{32}$

Indonesia sebagai negara hukum memiliki kekuasaan tidak tanpa batas, artinya kekuasaan harus tunduk pada hukum. Salah satu prinsip yang paling penting dalam negara hukum adalah semua orang sama dihadapan hukum, atau dengan kata lain hukum diperlakukan sama kepada semua orang tanpa perbedaan ras, agama, kedudukan sosial dan kekayaan. ${ }^{33}$ Salah satu fungsi yang terpenting dari hukum adalah tercapainya keteraturan dalam kehidupan manusia di dalam masyarakat sehingga dengan keteraturan orang dapat hidup dengan berkepastian, artinya

\footnotetext{
Airlangga, 1990, hlm. 75.

28 Ibid.

29 Ibid., hlm. 80.

${ }^{30}$ A.D. Belinfante, dalam Ridwan HR, Op.cit., hlm. 352.

${ }^{31}$ Satjipto Rahardjo, Masalah Penegakan Hukum Suatu Tinjauan Sosiologis, Bandung: Sinar Baru, Tanpa tahun, hlm. 15.

32 M. Yahya Harahap, Pembahasan Permasalahan dan Penerapan KUHP Penyidikan dan Penuntutan, Jakarta: Sinar Grafika, 2002, hlm. 76.

${ }^{33}$ Mochtar Kusumaatmadja, Arief Sidharta, Pengantar Ilmu Hukum Suatu Pengenalan Pertama Ruang Lingkup Berlakunya Ilmu Hukum, Buku I, Bandung: Alumni, 2009, hlm. 134-135.
} 
dalam kehidupan bermasyarakat orang dapat mengadakan suatu perbuatan yang dibutuhkan sehingga dapat mengadakan perhitungan tentang apa yang diharapkan. Inti dari keteraturan adalah kepastian dan apabila dihubungkan baik kepentingan penjagaan keamanan diri maupun harta milik dapat pula disebut ketertiban. ${ }^{34}$

Konsepsi negara hukum merupakan landasan terwujudnya kepastian hukum. ${ }^{35}$ Ciri negara hukum menurut Friedrich Julius Stahl, ${ }^{36}$ antara lain adalah adanya perlindungan terhadap hak asasi manusia, adanya pemisahan atau pembagian kekuasaan, pemerintah bertindak berdasarkan peraturan perundang-undangan (wetmatigheid van bestuur), dan adanya peradilan administrasi dalam penyelesaian perselisihan. Konsep negara hukum mencakup pula masalah kesejahteraan sosial (welfare state) yang dimuat dalam konstitusi tertulis sebagaimana diatur dalam Pasal 28 I ayat (5) UUD 1945 tentang perlindungan hak asasi manusia yang dikenal dengan prinsip negara hukum yang demokratis. ${ }^{37}$

Kepastian hukum adalah 'sicherkeid des Rechts selbst' (kepastian tentang hukum itu sendiri). Terdapat empat hal yang berhubungan dengan makna kepastian hukum. Pertama, bahwa hukum positif artinya perundang-undangan itu sendiri (gesetzliches Rechts). Kedua, bahwa hukum harus didasarkan pada fakta (tatsachen), bukan rumusan tentang penilaian yang nanti akan dilakukan oleh hakim, seperti 'kemauan baik', 'kesopanan'. Ketiga, bahwa suatu fakta harus dirumuskan dengan cara yang jelas sehingga menghindari dari kekeliruan dalam pemaknaan, disamping juga mudah dijalankan. Keempat, hukum positif tidak boleh diubah-ubah. ${ }^{38}$

Masalah kepastian hukum dalam kaitannya dengan pelaksanaan hukum, memang sama sekali tak dapat dilepaskan dari perilaku manusia. Kepastian hukum bukan mengikuti prinsip 'pencet tombol', melainkan sesuatu yang cukup rumit, yang banyak berkaitan dengan faktor di luar hukum itu sendiri. Berbicara mengenai kepastian, maka seperti dikatakan Radbruch, yang lebih tepat adalah kepastian dari adanya peraturan itu sendiri atau kepastian peraturan (sicherkeit des rechts). ${ }^{39}$

Menurut Satjipto Rahardjo, ${ }^{40}$ kepastian yang diberikan hukum tidak saja menjelma dalam peraturan tetapi dalam perilaku. Kepastian hukum itu dapat

\footnotetext{
34 Ibid., hlm. 49-50.

35 Fachmi, kepastian Hukum mengenai Batal Demi Hukum Dalam Sistem Peradilan Pidana Indonesia, Bogor: Ghalia Indonesia Publishing, 2011, hlm. 20.

${ }^{36}$ Dikutip dari Oemar Seno Adji, Prasaran Dalam Seminar Ketatanegaraan UUD 1945, Jakarta: Seruling Masa, 1996, hlm. 24. Dapat dilihat juga Moh. Mahfud MD, Demokrasi dan Konstitusi di Indonesia, Yogyakarta: Liberty, 1993, Cet. Pertama, hIm. 27-28 dalam Fachmi, Ibid.

37 Pasal 28 I ayat (5) UUD 1945 (Perubahan Ke-2) berbunyi: "untuk menegakkan dan melindungi hak asasi manusia sesuai dengan prinsip negara hukum yang demokratis, pelaksanaan hak asasi manusia dijamin, diatur dan dituangkan dalam peraturan perundang-undangan".

38 Satjipto Rahardjo, Hukum Dalam Jagat Ketertiban, Jakarta: UKI Press, 2006, hlm. 135-136.

39 Rudbruch, dalam Satjipto Raharjo, Ibid., hlm. 139.

${ }^{40}$ Satjipto Rahardjo, Kepastian Hukum dan Kekuatan Bangsa, Kompas, edisi Rabu 18 Januari 2006. HIm. 7. Satjipto
} 
diwujudkan dalam bentuk kepastian undang-undang, yaitu adanya konsistensi dalam penerapan asas undang-undang. Selain itu, kepastian hukum juga harus diwujudkan dalam implementasinya, yaitu kesatuan hukum dan tindakan. Selanjutnya, untuk mewujudkan ketertiban itu manusia berperilaku dengan cara tertentu yang dirumuskan dalam bentuk kaidah. Ketertiban dan kaidah yang diperlukan manusia adalah ketertiban dan kaidah yang secara otentik menciptakan kondisi yang memungkinkan manusia secara wajar mewujudkan kepribadiannya secara utuh. Atas dasar pemikiran seperti itu, Thomas Aquinas ${ }^{41}$ menegaskan bahwa hukum adalah penataan pemikiran demi kebaikan bersama yang dipublikasikan oleh mereka yang peduli kepada ketertiban masyarakat.

Agar hubungan hukum antar subjek hukum itu berjalan secara harmonis, seimbang, dan adil; dalam arti setiap subjek hukum mendapatkan apa yang menjadi haknya dan menjalankan kewajiban yang dibebankan kepadanya; hukum tampil sebagai aturan main dalam mengatur hubungan hukum tersebut. Hukum diciptakan sebagai suatu sarana atau instrumen untuk mengatur hak-hak dan kewajiban-kewajiban subjek hukum agar masing-masing subjek dapat menjalankan kewajibannya dengan baik dan mendapatkan haknya secara wajar. ${ }^{42}$ Di samping itu, hukum juga berfungsi sebagai instrumen perlindungan bagi subjek hukum.

Hukum berfungsi sebagai pelindung kepentingan manusia. Agar kepentingan manusia terlindungi, hukum harus dilaksanakan. Pelaksanaan hukum dapat berlangsung secara normal, damai, tetapi dapat terjadi juga karena pelanggaran hukum. Pelanggaran hukum terjadi ketika subjek hukum tertentu tidak menjalankan kewajiban yang seharusnya dijalankan atau karena melanggar hakhak subjek hukum lain. Subjek hukum yang dilanggar hak-haknya harus mendapatkan perlindungan hukum. ${ }^{43}$

Perlindungan hukum bagi rakyat merupakan konsep universal, dalam arti dianut dan diterapkan oleh setiap negara yang mengedepankan diri sebagai negara hukum. Seperti disebutkan Paulus E. Lotulung, masing-masing negara mempunyai cara dan mekanismenya sendiri tentang bagaimana mewujudkan perlindungan hukum tersebut, dan sampai seberapa jauh perlindungan hukum itu diberikan.

Rahardjo menjelaskan, bahwa ketika seorang investor membutuhkan kepastian modalnya akan selamat, maka dibutuhkan prediktabilitas, jawabannya adalah hukum. Hukum mampu memberikan prediktabilitas, di Indonesia kondisi sekarang syaratnya tidak saja adanya reformasi undang-undang dan sistem, tetapi meliputi reformasi perilaku manusia.

41 Thomas Aquinas, dalam B. Arief Sidharta, Aliran Filsafat dan Hukum, Makalah dalam Seminar Nasional; Menata Sistem Hukum Nasional Menuju Indonesia Baru, Yogyakarta: Sema FH Universitas Atma Jaya, 4 Desember 1999, hlm. 2 .

42 Ibid.

${ }^{43}$ Sudikno Mertokusumo, Op. cit., hlm. 140. 
Perlindungan yang dimaksudkan dalam hal ini lebih ditekankan pada perlindungan hukum terhadap sikap tindak atau perbuatan hukum pemerintah berdasarkan hukum positif di Indonesia. ${ }^{44}$

Sehubungan dengan pendirian PT sebagai badan hukum, para pihak yang berkepentingan juga harus memperoleh kepastian hukum dan perlindungan hukum, baik dari segi peraturannya maupun pelaksanaannya. Pasal 10 ayat (3), ayat (4), dan ayat (5) UU PT mengatur tentang format isian dan keterangan mengenai dokumen pendukung yang telah sesuai dengan ketentuan peraturan perundangundangan. Menteri langsung menyatakan tidak berkeberatan atas permohonan yang bersangkutan secara elektronik. Apabila format isian yang tidak sesuai dengan peraturan perundang-undangan, Menteri langsung memberitahukan penolakan beserta alasannya kepada pemohon. Dalam jangka waktu paling lambat 30 hari terhitung sejak tanggal pernyataan tidak berkeberatan sebagaimana dimaksud, pemohon yang bersangkutan wajib menyampaikan secara fisik surat permohonan yang dilampiri dokumen pendukung.

Praktik SABH berkaitan dengan pasal di atas dalam pelaksanaannya belum dijalankan sebagaimana semestinya. Menteri tidak memberitahukan penolakan berikut alasannya apabila dokumen pendukung tidak sesuai dengan ketentuan perundang-undangan. Diperkuat lagi dengan ketentuan Pasal 16 Permenkumham 4/2014 yang menyatakan bahwa, "dalam hal format pendirian PT yang dilengkapi dokumen pendukung tidak sesuai dengan ketentuan peraturan perundangundangan, maka keputusan Menteri tersebut dicabut". Terdapat pertentangan antara Pasal 10 ayat (4) UU PT 2007 dengan peraturan pelaksananya. Praktik SABH, pemohon tidak menyampaikan secara fisik surat permohonan yang dilampiri dokumen pendukung. Hal ini tentu tidak sejalan dengan ketentuan sebagaimana dimaksud Pasal 10 ayat (5) UU PT 2007. Pemerintah tidak konsisten dalam menjalankan perintah UU PT 2007 khususnya Pasal 10 ayat (4) dan ayat (5) tersebut sehingga mengabaikan kepastian hukum dan perlindungan hukum.

Sebagai perwujudan dari negara hukum, diantaranya kepastian hukum dan perlindungan hukum, penyelenggara negara dan pemerintahan dalam melaksanakan kewenangannya harus berdasarkan peraturan perundangundangan. Peraturan perundang-undangan yang berlaku mulai dari tingkat tertinggi, yaitu undang-undang dasar dan selanjutnya dijabarkan lebih lanjut dalam peraturan perundang-undangan di bawahnya.

Lebih lanjut, menurut ketentuan Pasal 10 ayat (6) dan ayat (7) UU PT 2007, apabila semua persyaratan sebagaimana dimaksud telah dipenuhi secara lengkap, paling lambat 14 hari menteri menerbitkan keputusan tentang pengesahan badan

44 Ibid. 
hukum PT yang ditandatangani secara elektronik, dan apabila persyaratan tentang jangka waktu dan kelengkapan dokumen pendukung sebagaimana dimaksud tidak dipenuhi, menteri langsung memberitahukan hal tersebut kepada pemohon secara elektronik dan pernyataan tidak keberatan dimaksud menjadi gugur.

Praktik SABH PT berkaitan dengan ketentuan pasal di atas, apabila semua persyaratan telah dipenuhi secara lengkap notaris sebagai kuasa dari para pendiri wajib mengisi surat pernyataan secara elektronik yang menyatakan bahwa format pendirian PT dan keterangan mengenai dokumen pendukung telah sesuai dengan ketentuan peraturan perundang-undangan yang berlaku. Selanjutnya, pemohon bertanggung jawab penuh terhadap format pendirian PT dan keterangan tersebut.

Notaris selaku pemohon dapat langsung melakukan pencetakan sendiri keputusan Menteri mengenai pengesahan pendirian PT sebagai badan hukum, dengan menggunakan kertas berwarna putih ukuran F4/folio dengan berat 80 gram. Keputusan Menteri sebagaimana dimaksud wajib ditandatangani dan dibubuhi cap jabatan notaris serta memuat frasa yang menyatakan 'Keputusan Menteri ini dicetak dari SABH'. Praktik SABH PT yang berkaitan dengan persyaratan jangka waktu dan kelengkapan dokumen sebagaimana dimaksud tidak dijalankan sesuai perintah Pasal 10 UU PT 2007. Menteri tidak melakukan pemberitahuan kepada pemohon secara elektronik apabila pemohon tidak melengkapi dokumen pendukung sesuai jangka waktu yang telah ditetapkan.

Pemerintah tidak konsisten dalam menjalankan perintah Pasal 10 ayat (6) UUPT 2007 tersebut. Hal ini bertentangan dengan prinsip, bahwa hukum sebagai dasar dalam segala aktivitas kehidupan bermasyarakat, bernegara, dan berbangsa untuk mencapai masyarakat adil dan makmur secara merata. Oleh karena itu, segala tindakan baik yang dilakukan oleh penyelenggara negara maupun rakyat harus sesuai atau tidak bertentangan dengan hukum yang berlaku. Dengan dimikian, tujuan hukum yang dicita-citakan, yaitu kepastian dan perlindungan hukum dapat terwujud dengan baik.

Perbuatan pemerintah yang dapat menimbulkan kerugian bagi masyarakat dan atau bagi seseorang atau badan hukum perdata dapat berupa perbuatan pemerintah dalam bidang pembuatan peraturan perundang-undangan (regeling), perbuatan pemerintah dalam penerbitan ketetapan (beschiking), dan perbuatan pemerintah dalam bidang keperdataan (materiele daad). ${ }^{45}$ Perlindungan hukum terhadap warga negara menurut Sjachran Basah, diberikan apabila perbuatan administrasi negara menimbulkan kerugian terhadapnya, sedangkan perlindungan terhadap administrasi negara dilakukan terhadap sikap tindaknya dengan baik dan benar menurut hukum baik tertulis maupun tidak tertulis. ${ }^{46}$

\footnotetext{
${ }^{45}$ Ridwan HR, Op. cit., hlm. 282-283.

${ }^{46}$ Sjachran Basah, Perlindungan Hukum Atas Sikap Tindak Administrasi Negara, Bandung: Alumni, 1992, hlm. 7-8.
} 
Perlindungan hukum bagi rakyat dapat berupa perlindungan hukum preventif dan represif. Mengenai perlindungan hukum preventif, rakyat diberikan kesempatan untuk mengajukan keberatan atau pendapatnya sebelum keputusan pemerintah secara definitif ditetapkan. Hal ini mengandung arti bahwa perlindungan hukum preventif bertujuan mencegah terjadinya sengketa. Perlindungan hukum represif bertujuan untuk menyelesaikan sengketa yang terjadi. ${ }^{47}$ Terdapat beberapa alasan mengapa warga negara harus memperoleh perlindungan hukum atas tindakan pemerintah, diantaranya adalah karena warga negara dan badan hukum perdata dalam berbagai hal tergantung kepada keputusan-keputusan dan ketetapan pemerintah. Oleh karena itu, warga negara dan badan hukum perdata perlu mendapat perlindungan hukum sehingga akan tercapai kepastian hukum dan jaminan keamanan. ${ }^{48}$

Hubungan antara pemerintah dengan warga negara tidak berjalan sejajar, posisi warga negara lemah dibandingkan dengan pemerintah. Setiap perselisihan antara warga negara dengan pemerintah yang berkenaan dengan keputusan dan ketetapan yang bersifat sepihak dalam melakukan intervensi terhadap kehidupan warga negara, sehingga pelanggaran terhadap hak-hak rakyat semakin terbuka. Secara khusus Pasal 1365 KUHPerdata mengatur tentang perbuatan melawan hukum, pasal tersebut berbunyi sebagai berikut, "Tiap perbuatan melanggar hukum yang membawa kerugian kepada orang lain, mewajibkan orang yang karena salahnya menerbitkan kerugian itu, mengganti kerugian tersebut".

Sebagai tolok ukur perbuatan melawan hukum yang dilakukan oleh penguasa menurut putusan Mahkamah Agung dalam perkara Kasum (Putusan Nomor 66K/Sip/1952), bahwa perbuatan melawan hukum terjadi apabila terdapat perbuatan sewenang-wenang dari pemerintah atau merupakan tindakan yang tidak cukup melindungi kepentingan umum. Selanjutnya, putusan Mahkamah Agung dalam perkara Josopandojo (Putusan Nomor 838K/Sip/1970) disebutkan bahwa kriteria perbuatan melawan hukum adalah undang-undang dan peraturan formal berlaku, kepatutan dalam masyarakat yang harus dipatuhi oleh penguasa, dan perbuatan kebijaksanaan dari pemerintah tidak termasuk kompetensi pengadilan. ${ }^{50}$

Berdasarkan putusan Mahkamah Agung tersebut, kriteria perbuatan melawan hukum oleh penguasa adalah meliputi baik perbuatan yang melanggar undangundang dan peraturan formal yang berlaku maupun perbuatan melanggar

\footnotetext{
47 Ridwan HR, Op. cit., hlm. 292.

48 Ibid.

49 Ibid., hlm. 293.

50 lbid., hlm. 288.
} 
kepentingan dalam masyarakat yang seharusnya dipatuhinya. ${ }^{51}$ Perlindungan hukum bagi rakyat dari tindakan hukum pemerintah yang dalam kapasitasnya sebagai wakil dari badan hukum publik, dapat dilakukan melalui peradilan umum. Hukum perdata memberikan perlindungan hukum yang sama baik kepada pemerintah maupun seseorang atau badan hukum. Dengan demikian kedudukan hukum antara penguasa dan rakyat adalah sejajar sehingga prinsip kedudukan yang sama di depan hukum (equality before the law) yang menjadi salah satu unsur negara hukum. ${ }^{52}$ Lebih lanjut, berdasarkan putusan Hoge Raad dalam perkara Lindennaum Cohen pada tahun 1919 terdapat 4 kriteria perbuatan melanggar hukum, yakni: ${ }^{53}$

1. Bertentangan dengan kewajiban hukum si pelaku;

2. Melanggar hak subjektif orang lain;

3. Melanggar kaidah tata susila;

4. Bertentangan dengan asas kepatutan, ketelitian serta sikap hati-hati yang seharusnya dimiliki seseorang dalam pergaulan dengan sesama warga masyarakat atau terhadap harta benda orang lain.

Suatu perbuatan yang bertentangan dengan kewajiban menurut undangundang dimaksudkan setiap ketentuan umum yang bersifat mengikat dan dikeluarkan oleh kekuasaan yang berwenang, merupakan perbuatan melanggar hukum. ${ }^{54}$ Ketentuan umum dimaksud termasuk dalam ruang lingkup hukum publik, juga peraturan hukum pidana. Pelanggaran terhadap hukum pidana tidak hanya bersifat melawan hukum (wederrechtelijk) dalam pengertian hukum pidana akan tetapi dalam keadaan tertentu dapat bersifat melanggar hukum (onrechtmatig) dalam pengertian hukum perdata, jadi setiap ketentuan umum yang bersifat mengikat termasuk dalam pengertian kewajiban hukum. ${ }^{55}$

Kerugian yang ditimbulkan oleh orang lain dengan melanggar ketentuan undang-undang baik dalam arti formil maupun materiil, maka orang tersebut melakukan suatu perbuatan melanggar hukum, yakni bertentangan dengan kewajiban hukumnya. ${ }^{56}$ Selanjutnya apabila seseorang melakukan perbuatan yang bertentangan kewajiban hukum pelaku tanpa membahayakan orang atau barang milik orang lain maka ia telah melakukan perbuatan melawan hukum (dalam pengertian hukum pidana), akan tetapi belum tentu melakukan perbuatan melanggar hukum dalam pengertian hukum perdata. ${ }^{57}$

\footnotetext{
51 Muchsan, Sistem Pengawasan Terhadap Perbuatan Aparat Pemerintah dan Peradilan Tata Usaha Negara di Indonesia, Yogyakarta: Liberty, 1997, hlm. 28.

52 Ridwan HR, Op. cit., hlm. 289.

53 Setiawan, Aneka Masalah Hukum Dan Hukum Acara Perdata, Bandung: Alumni, 1992, hlm. 251.

54 Ibid., hlm. 252.

55 Ibid.

56 Ibid., hlm. 253.

57 Ibid.
} 
Berdasarkan putusan Hoge Raad dari tahun 1883, suatu perbuatan atau tidak berbuat merupakan perbuatan melanggar hukum, apabila terjadi pelanggaran terhadap hak subjektif orang lain. ${ }^{58}$ Selanjutnya, pelanggaran terhadap kaidah tata susila dimaksudkan kaidah-kaidah moral yang diterima oleh masyarakat sebagai kaidah hukum tidak tertulis merupakan perbuatan melanggar hukum. ${ }^{59} \mathrm{Hal}$ ini dapat dilihat ketentuan Pasal 1335 dan Pasal 1337 KUHPerdata menentukan, bahwa suatu perjanjian yang bertentangan dengan kaidah tata susila tidak diperkenankan dan tidak memiliki kekuatan hukum. Merupakan suatu pendirian, bahwa sejak tahun 1927 suatu perjanjian yang bertentangan dengan kaidah tatasusila merupakan suatu perbuatan melanggar hukum terhadap pihak ketiga. ${ }^{60}$

\section{E. Penutup}

Berdasarkan hasil pembahasan pada bagian terdahulu, dapat disimpulkan hal-hal sebagai berikut:

1. Pengaturan SABH dalam UU PT 2007 dalam memenuhi kepastian hukum dan perlindungan hukum bagi stakeholders, belum sepenuhnya tercapai. Hal ini disebabkan pelaksanaan SABH tidak sejalan dengan pengaturan dalam UU PT 2007 dan peraturan pelaksanaan dari SABH telah beberapa kali mengalami perubahan.

2. Fungsi pengesahan anggaran dasar melalui SABH dalam praktik berkaitan dengan kepastian hukum dan perlindungan hukum bagi stakeholders, hanya untuk memperoleh status badan hukum PT dan belum dilakasanakan menurut Undang-Undang Nomor 30 Tahun 2014 Tentang Administrasi Pemerintahan. Hal ini disebabkan Menkumham sebagai pejabat yang berwenang menerbitkan keputusan tentang badan hukum PT tidak memeriksa dokumen dan kelengkapan administrasi pemerintahan dari pemohon.

3. Praktik SABH ke depan dalam pelaksanaan UU PT 2007 untuk dapat lebih mewujudkan kepastian hukum dan perlindungan hukum bagi stakeholders, harus ada kesesuaian antara peraturan dan pelaksanaan sehari-hari.

Terhadap hasil pembahasan di atas, saran-saran yang dapat diberikan:

1. Praktik SABH harus sesuai dengan UU PT 2007 sehingga perlu diadakan penyempurnaan terhadap UU PT 2007 yang berkaitan dengan pengaturan $\mathrm{SABH}$. Hal ini dikarenakan SABH tidak memberikan jaminan kepastian hukum dan perlindungan hukum bagi pihak-pihak yang berkepentingan. Secara praktis hasil penelitian ini diharap dapat bermanfaat bagi Pemerintah bersama-sama DPR untuk melakukan penyempurnaan terhadap undang-undang tersebut, Kemenkumham, melalui Dirjen AHU sebagai pelaksana dari $\mathrm{SABH}$, dan notaris.

\footnotetext{
58 Ibid., hlm. 260.

59 Ibid., hlm. 265.

${ }^{60}$ Dikutip dari Setiawan, Ibid., hlm. 266.
} 
2. Pertanggungjawaban pengesahan badan hukum PT oleh Pemerintah (dalam hal ini Kementerian Hukum dan HAM) tidak hanya dibebankan kepada para pendiri PT selaku pemohon dan notaris dalam kedudukan sebagai pejabat umum. Disarankan keadaan ini dapat berubah, Menteri turut bertanggung jawab terhadap apa yang sudah disahkan tersebut. Hal ini sesuai dengan prosedur dalam hukum administrasi negara, sebagai pihak yang berwenang menerbitkan suatu keputusan harus bertanggung jawab atas terbitnya keputusan yang telah dikeluarkan tersebut. Selanjutnya disarankan semua persyaratan mengenai dokumen pendukung yang berkaitan dengan pendirian PT berikut pengesahannya sebagai badan hukum tersebut, dapat dilakukan melalui sistem online sehingga diharapkan proses birokrasi dapat diakses dengan cepat dan menjamin kepastian hukum.

3. Disarankan status badan hukum PT diperoleh setelah akta pendirian PT telah selesai dilakukan di hadapan notaris. Hal ini disebabkan dengan cara tersebut diharapkan lebih mempercepat proses memperoleh status badan hukum PT dan dapat mempersingkat proses yang menyangkut masalah teknis administratif. Notaris yang bersangkutan hanya melaporkan kepada Menteri secara elektronik dengan telah didirikannya PT tersebut. Secara teoretis hasil kajian mengenai praktik pendirian PT berdasarkan pendaftaran dapat dijadikan landasan operasional bagi pendirian PT sebagai badan hukum.

\section{Daftar Pustaka}

\section{Buku}

Amrah Muslimin, Beberapa Asas-asas dan Pengertian-Pengertian Pokok Tentang Administrasi dan Hukum Administrasi, Bandung, Alumni, 1980.

E. Utrecht, Pengantar Hukum Administrasi Negara Indonesia, Bandung, Cet. Ke 4 FHPM Universitas Negeri Padjadjaran, 1960.

Fachmi, kepastian Hukum mengenai Batal Demi Hukum Dalam Sistem Peradilan Pidana Indonesia, Bogor, Ghalia Indonesia Publishing, 2011.

Iswi Hariyani, R. Serfianto Dibyo Purnomo, Cita Yustisia Serfiyani, Panduan Praktis SABH, Jakarta, Pustaka Yustisia, 2011.

Man S. Sastrawidjaja, Bunga Rampai Hukum Dagang, Alumni, Bandung, 2005. dan Rai Mantili, Perseroan Terbatas Menurut Tiga UndangUndang,Alumni, Bandung, 2008.

M. Yahya Harahap, Pembahasan Permasalahan dan Penerapan KUHP Penyidikan dan Penuntutan, Jakarta, Sinar Grafika, 2002. 
Mochtar Kusumaatmadja, Arief Sidharta, Pengantar IImu Hukum Suatu Pengenalan Pertama Ruang Lingkup Berlakunya Ilmu Hukum, Buku I, Bandung, Alumni, 2009.

Muchsan, Sistem Pengawasan Terhadap Perbuatan Aparat Pemerintah dan Peradilan Tata Usaha Negara dia Indonesia, Yogyakarta, Liberty, 1997.

Munir Fuady, Teori Negara Hukum Modern (Rechtstaat), Refika Aditama, Bandung, 2009.

Ridwan HR, Hukum Administrasi Negara, RajaGrafindo Persada, Jakarta, 2006.

Romli Atmasasmita, Teori Hukum Integratif Rekonstruksi Terhadap Teori Hukum Pembangunan dan Teori Hukum Progresif, Yogyakarta, Genta Publishing, 2012.

Satjipto Rahardjo, Masalah Penegakan Hukum Suatu Tinjauan Sosiologis, Bandung, Sinar Baru, Tanpa tahun ,Hukum Dalam Jagat Ketertiban, Jakarta, UKI Press, 2006

Sudikno Mertokusumo, Mengenal Hukum, Suatu Pengantar, Yogyakarta, Liberty, 1996.

Wiratni Ahmadi, Perlindungan Hukum Bagi Wajib Pajak Dalam Penyelesaian Sengketa Pajak, Bandung, Refika Aditama, Cet ke-1, 2006.

\section{Dokumen Lain}

Rukmana Amanwinata, Pengaturan dan batas Implementasi Kemerdekaan Berserikat dan Berkumpul dalam Pasal 28UUD1945,Disertasi Fakultas Hukum Pasca Sarjana Universitas Padjadjaran, Bandung, 1996.

Suwoto, Kekuasaan dan Tanggung Jawab Presiden Republik Indonesia, Disertasi, Surabaya, Universitas Airlangga, 1990.

\section{Dokumen Hukum}

Undang-Undang Dasar Republik Indonesia Tahun 1945

Undang-Undang Nomor 40 Tahun 2007 tentang Perseroan Terbatas

Undang-Undang Nomor 30 Tahun 2014 tentang Administrasi Pemerintahan

Peraturan Menteri Hukum dan Hak Asasi Manusia Republik Indonesia Nomor:

M.HH-01.AH.01.01 Tahun 2011 tentang Tata Cara Pengajuan Permohonan Pengesahan Badan Hukum dan Persetujuan Perubahan Anggaran Dasar serta Penyampaian Pemberitahuan Perubahan Anggaran Dasar dan Perubahan Data Perseroan Terbatas

Peraturan Menteri Hukum dan Hak Asasi Manusia Republik Indonesia Nomor: 4 Tahun 2014 tentang Tata Cara Pengajuan Permohonan Pengesahan Badan Hukum dan Persetujuan Perubahan Anggaran Dasar Serta Penyampaian Pemberitahuan Perubahan Anggaran Dasar Dan Perubahan Data Perseroan Terbatas. 